\title{
Інна Іртищева
}

доктор економічних наук, професор, проректор з науково-педагогічної роботи та інновачійної діяльності Національного університету кораблебудування імені адмірала Макарова, м. Миколаїв, Україна,e-mail:innauamd@gmail.com https://orcid.org/0000-0002-7025-9857

\section{Анатолій Носар}

здобувач Міжнародного університету бізнесу і права, м. Херсон, Украӥна, e-mail:management@nuos.edu.ua, https://orcid.org/0000-0001-6225-5277

\section{СТРАТЕГІЧНІ ОРІЄНТИРИ РОЗВИТКУ СКЛАДСЬКОЇ ЛОГІСТИКИ ЯК СКЛАДОВОЇ ТРАНСПОРТНО-ЛОГІСТИЧНИХ СИСТЕМ РЕГІОНУ}

Анотація: На основі дослідження досвіду провідних світових логістичних компаній систематизовано основні інноваційні тренди розвитку сучасної складської логістики, визначено їх переваги, недоліки та можливості впровадження на вітчизняних підприємствах. Визначено, що основними інноваційними трендами розвитку складської логістики на сучасному етапі $\epsilon$ інтеграція інформаційних, соціальних, комунікаційних технологій а також формування на цій основі оцифрованих матеріально-речових систем «Смартскладів» інтегрованих у функціонально-спрямовані мережеві системи, що дозволяють здійснювати управління складськими процесами у режимі реального часу відповідно до змін ринкової ситуації, потреб клієнтів, транспортних потоків та забезпечувати дотримання стандартів всіх складських операцій при мінімізації витрат.

Досліджено, що сучасний стан та темпи впровадження інноваційних технологій у транспортно-логістичній сфері в Україні $\epsilon$ недостатніми для забезпечення належного конкурентного рівня розвитку економіки та іiі інтеграції в світові і Європейські транспортно-логістичні системи. Інновації впродовж останні чотирьох років впроваджували всього 18\% українських транспортнологістичних компаній, більшість з яких організаційні і маркетингові. Попри значний прогрес за останні 10 років, на Україні, а зокрема в окремих регіонах, існує значний дефіцит на новітні технології та обладнані згідно міжнародних стандартів складські приміщення. Потенціал інформаційних технологій також не використовується у повному обсязі через недостатність фінансування інноваційної діяльності, брак кваліфікованих кадрів в даній сфері та недостатньо розвинену інфраструктуру зв'язку на окремих територіях.

Ключові слова: стратегія, складська логістика, регіон, Європейські транспортно-логістичні системи, «Смарт-складів». 


\section{Inna Irtyshcheva}

Doctor of Economics, Professor,

Vice-Rector for Research and Teaching and Innovation of the Admiral Makarov National University of Shipbuilding, Mykolaiv, Ukraine, e-mail: innauamd@gmail.com https://orcid.org/0000-0002-7025-9857

\section{Anatoliy Nosar}

Getter of the International University of Business and Law, Kherson, Ukraine, e-mail:management@nuos.edu.ua, https://orcid.org/0000-0001-6225-5277

\section{STRATEGIC ORIENTATIONS FOR THE DEVELOPMENT OF WAREHOUSE LOGISTICS AS A COMPONENT OF TRANSPORT AND LOGISTICS SYSTEMS OF THE REGION}

Abstract: Based on the study of the experience of the world's leading logistics companies, the main innovative trends in the development of modern warehousing logistics are systematized, their advantages, disadvantages and opportunities for implementation at domestic enterprises are identified. It is determined that the main innovative trends in the development of warehousing logistics at the present stage is the integration of information, social, communication technologies and the formation on this basis of digitized material systems "Smart Warehouses" integrated into functionally oriented network systems to manage warehouse processes. in real time in accordance with changes in the market situation, customer needs, traffic flows and ensure compliance with the standards of all warehousing operations while minimizing costs.

It is investigated that the current state and pace of implementation of innovative technologies in the transport and logistics sector in Ukraine are insufficient to ensure a proper competitive level of economic development and its integration into the world and European transport and logistics systems. Over the past four years, only $18 \%$ of Ukrainian transport and logistics companies have implemented innovations, most of which are organizational and marketing. Despite significant progress over the past 10 years, in Ukraine, and in particular in some regions, there is a significant shortage of the latest technologies and warehouses equipped according to international standards. The potential of information technology is also not fully used due to insufficient funding for innovation, lack of qualified personnel in this area and underdeveloped communication infrastructure in some areas.

Keywords: strategy, warehouse logistics, region, European transport and logistics systems, "Smart warehouses".

Постановка проблеми. В умовах сучасних умовах глобалізації, інтернаціоналізації та трансформації ринків зростає роль транспортнологістичних систем та відповідних логістичних центів у забезпеченні економічного розвитку, безпеки та конкурентоспроможності економіки на глобальному, національному та регіональному рівнях. 
Аналіз останніх досліджень та публікацій. Питання аналізу основних трендів сфери логістики висвітлюються у багатьох дослідженнях вітчизняних i закордонних вчених, експертів міністерств, відомств та департаментів, державних і громадських агенцій.

Мета статті: обгрунтувати стратегію розвитку складської логістики як складової транспортно-логістичних систем регіону.

Виклад основного матеріалу. На думку Войт С.М. та Завгороднього К.В, «глобалізація ринків сировинних матеріалів та ринків збуту готової продукції визначають характер та обсяги вантажопотоків, які реалізуються при синхронізованої роботі різних видів транспорту, а також просторову концентрацію транспортно-складських комплексів, зорієнтованих на мінімізацію витрат, пов'язаних із транспортуванням та зберіганням матеріальних ресурсів. Існуюча світова практика ведення бізнесу характеризується високим рівнем інтеграції та організації бізнес-процесів, пов'язаних 3 обслуговуванням вантажного потоку, між усіма ланками транспортно-логістичного ланцюга за логістичними принципами «від дверей до дверей», «точно в строк» та «оптимальні витрати»» [1, с. 730].

Отже, світові тенденції розвитку транспортно-логістичних систем передбачають інтеграцію транспортних, інформаційних технологій та регіональних проектів мобільності. При цьому, складські системи відіграють роль інтегруючих створюваних елементів транспортно-логістичних комплексів а рівень їх організації, технологічності, стандартизації та відповідність потребам логістичного-ринку $є$ одним 3 важливих чинників оцінювання логістичних компетенцій країни та окремих регіонів.

Станом на кінець 2018 року за рівнем розвитку логістики Україна займає 66 iз 160 країн за міжнародним рейтингом логістики (LPI), що кожні 2 роки публікується всесвітнім банком [2].

Порівняно 3 попереднім періодом, національна транспортно-логістична система піднялася на 14 сходинок. Позиції України у міжнародному рейтингу логістики за період 2012-2018 років наведено на рис. 1.

Аналіз субідексів ефективності логістики показує в 5-тибальній шкалі основні сильні та слабкі сторони транспортно-логістичних систем порівняно 3 аналогічними в інших країнах світу. Найвищими впродовж дослідженого періоду $\epsilon$ показники своєчасності доставки вантажів. що позитивно характеризують Україну у якості надання транзитних послуг. Вищі за середні бали також в Україні за субіндексами вантажних перевезень у середньому (2,80 бали) та систем відслідковування вантажів $(3,15)$. Порівняно 3 попереднім періодом знижується оцінка транспортної інфраструктури (3 2,69 до 2,2) бали, що пов'язано насамперед із зносом основних засобів у галузі та станом дорожнього покриття. Найбільш низькими є показники роботи таможенних служб у зв'язку 3 неефективними адміністративними процедурами та наявністю високого рівня корупції. Орієнтуючись на дані показники можна побачити, що наразі наявний логістичний потенціал України використовується у середньому на 2,83 бали 3 5ти, а структура загального коефіцієнта дозволяє виділити основні слабкі сторони системи, серед яких: бюрократія, обмеженість та неефективне використання 
інвестицій, недостатність кваліфікованих кадрів, недостатні темпи впровадження інноваційних технологій та європейських стандартів логістичного обслуговування.

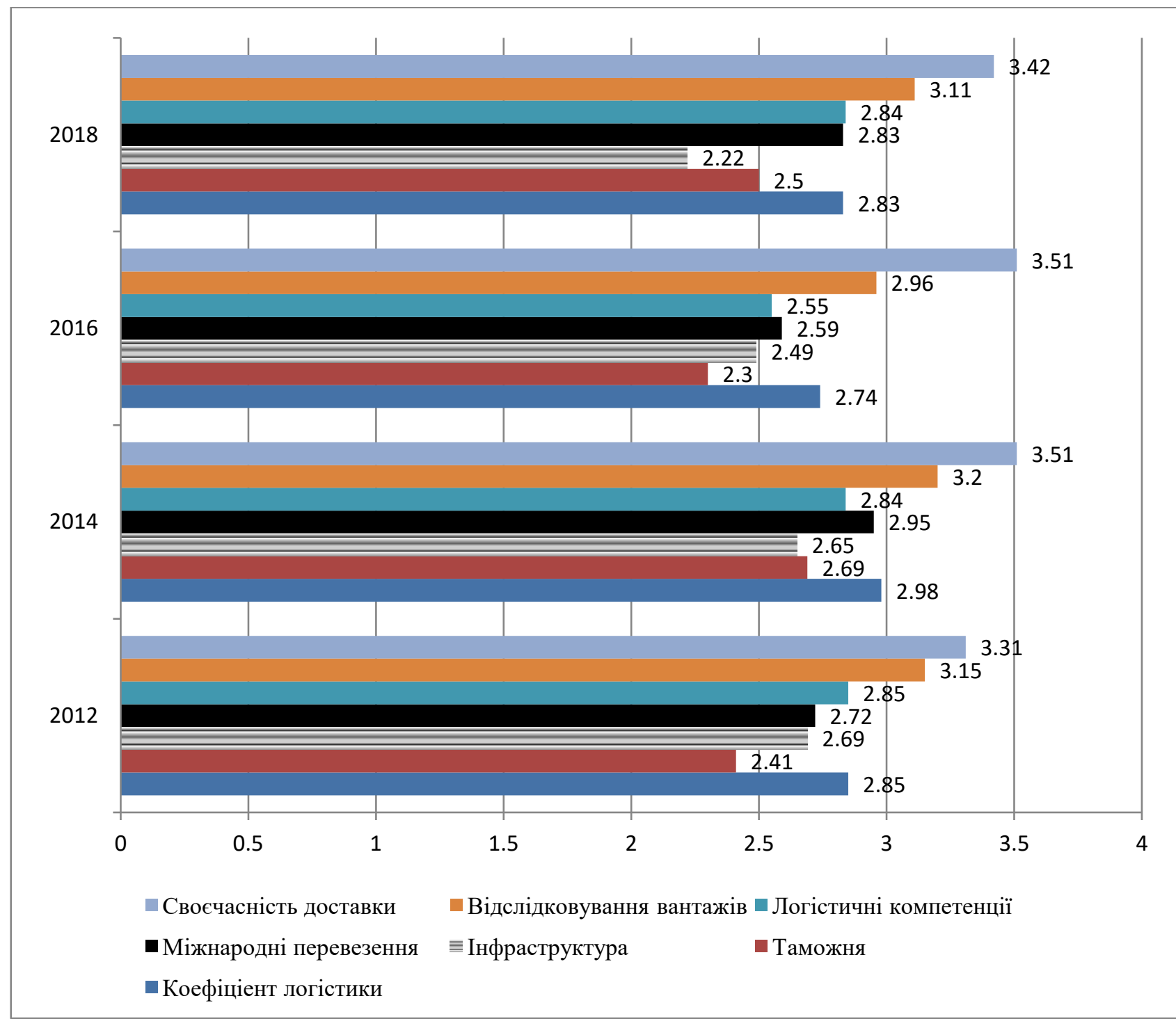

Рис. 1. Динаміка субіндексів оцінки ефективності транспортно-логістичних систем України

Джерело: систематизовано автором за даними Світового Банку [2]

Як зазначає Устенко М.А., «для транспортної системи будь-якої держави активна участь у глобалізації ринку транспортних послуг означає:

- лібералізацію усіх сфер транспортної діяльності, відмову від державного регулювання, що спричинюється, отже, до зростання конкуренції;

- уніфікацію і універсалізацію транспортних засобів, технологій, технічних вимог, активний розвиток і модернізацію транспортної інфраструктури;

- зростання транспарентності ринку транспортних послуг, зростання інформаційної відкритості (зокрема фінансову інформацію), підпорядкування діяльності транспортних компаній вимогам закону і міжнародних угод» [3, с.86].

Розвиток логістичної діяльності в Україні та перспективні можливості подальшого зростання іï питомої ваги у ВВП визначаються такими факторами: 
- географічне положення та наявний транзитний потенціал;

- наявність розгалуженої транспортної мережі, що представлена всіма видами транспорту (автомобільний, авіаційний , залізничний, водний);

- розвиток сільського господарства;

- розвиток сектору торгівлі та ритейлу;

- ріст ринку електронної торгівлі;

- розвиток інформаційно-комп'ютерних технологій та розбудова сектору зв'язку.

Всі наведені чинники в сукупності формують зростаючі потреби у розвитку ринку професійної логістики та розбудови логістичної інфраструктури.

Разом $з$ цим, погоджуємося $з$ авторами Пархаєвою. Н. В. та Колосовою Б. В., що «на сьогодні Україна значно відстає від світового рівня розвитку логістичних систем, і до стримуючих факторів має бути віднесено: недостатній рівень розвитку мережі автодоріг, відсутність сучасних вантажних терміналів, високий рівень зношування автомобільного, залізничного й іншого видів транспортного парку, а також все більше його моральне старіння; невелика кількість якісних сучасних складських комплексів 3 необхідним спеціалізованим устаткуванням, що відповідають світовим логістичним потребам; низький рівень впровадження систем зв'язку, через що в багатьох логістичних компаніях виникають складності 3 відстеженням логістичних ланцюжків і процесу транспортування вантажів по країні та за їі межами; слабкий розвиток промисловості з виробництва сучасної тари і упаковки; гостра недостача кваліфікованих фахівців, які на високому рівні орієнтуються в сучасних принципах організації логістичних схем просування матеріальних потоків та мають навички швидкого реагування в мінливих ринкових умовах; відсутність ефективного механізму партнерських взаємин між фірмами та підприємствами» [4].

Проведені дослідження засвідчують, що попри зростання уваги органів державної влади та місцевого самоврядування до розвитку транспортної інфраструктури на територіях, питанням складської логістики у документах стратегічного типу не приділяється значна увага. Основними завданнями стратегій всіх рівнів є насамперед розвиток транспортної інфраструктури (ремонт автошляхів, портів, модернізація аеропортів та інфраструктури залізничного сполучення).

На нашу думку, додаткова увага та стимулювання розвитку складської логістики дозволить підняти на вищий рівень ділову активність у регіоні та сприятиме вирішенню ряду важливих проблем, зокрема економічних (зростання прибутковості пріоритетних секторів економічної діяльності завдяки скороченню логістичних витрат, зростання податкових надходжень у місцеві бюджети), соціальних (зростання зайнятості, забезпечення продовольчої безпеки, розвиток людського капіталу) та екологічних (будівництво складських приміщень у зонах, що суттєво не впливають на стан навколишнього середовища, контроль техніки безпеки та якості застосовуваних технологій транспортування і зберігання).

Дана сфера діяльності в Україні вважається проблемою бізнесу, оскільки саме підприємці зацікавлені в будівництві та облаштуванні складських приміщень відповідно до напрямків розвитку бізнесу. Проте, без створення 
необхідних умов, бізнес обмежуватиметься лише мінімальними інвестиціями для підтримки певного рівня виробництва і збуту. Опосередковано, окремі напрямки розвитку складської логістики згадуються в таких стратегічних документах, як «Національна транспортна стратегія на період до 2030 року» [5], Проект стратегії сталої логістики та Плану дій уряду» [6], «Стратегія реформування управління життєвим циклом інфраструктурного проекту в Україні на 2020-2024 роки» [7] а також у Державній стратегії регіонального розвитку на 2020-2027 роки [8] та Стратегії соціально-економічного розвитку областей до 2027 року.

Зокрема, у Транспортній стратегії зазначаються основні завдання розвитку транспортно-логістичної системи України, що у тому числі стосуються розвитку складської логістики:

- Запровадження механізму стимулювання поетапної модернізації та розвитку транспортної інфраструктури, оновлення транспортних засобів для потреб галузі, зокрема удосконалення системи управління розвитком транспортної інфраструктури та виконання плану розвитку транспортної мережі на основі національної транспортної моделі;

- запровадження дієвого механізму оподаткування для залучення приватного капіталу в розвиток різних видів транспорту;

- удосконалення на законодавчому рівні механізму використання державноприватного партнерства під час реалізації проектів 3 розбудови транспортної інфраструктури;

- перехід до планового та стабільного фінансування будівництва та утримання автомобільних доріг у середньо- та довгостроковій перспективі;

- удосконалення законодавства щодо вироблення спрощеного механізму вилучення та викупу земельних ділянок для розвитку транспортної інфраструктури, передачі земель в концесію для будівництва автомобільних доріг та оформлення підприємствам та організаціям транспорту земельних ділянок у користування;

- удосконалення законодавства та економічного механізму сприяння локалізації кращих інноваційних технологій будівництва транспортної інфраструктури, виробництва та оновлення рухомого складу на базі вітчизняних підприємств, зокрема стимулювання розвитку їх зовнішньоекономічної діяльності шляхом встановлення митних пільг;

- вироблення прозорого механізму визначення пріоритетів публічних закупівель, їх обгрунтованої технічної та економічної доцільності, аналізу витрат і доходів;

- впровадження довгострокового фінансового планування реалізації інфраструктурних проектів в транспортній галузі відповідно до стратегічних пріоритетів, строку реалізації та життєвого циклу об'єктів транспорту 3 пріоритизацією проектів, що пов'язані з мережею TEN-T;

- створення уніфікованої (єдиної) системи координації, планування, залучення та моніторингу міжнародної допомоги для ефективного розподілу інвестицій за пріоритетами розвитку транспортної галузі [5].

У регіональному вимірі складська логістика розглядається як важлива складова та один $з$ провідних бізнес-процесів транспортно-логістичних систем. 
Саме тому, стратегія розвитку складської логістики може виступати у якості наскрізних проектів у стратегії розбудови транспортно-логістичних систем регіону та найбільш ефективно розміщуватися відносно основних об'єктів попиту на відповідні складські послуги.

Отже, стратегія розвитку складської логістики є безперечною важливою складовою розвитку транспортно-логістичної інфраструктури як регіону так i національної економіки в цілому, а ефективність іiі організації впливає на формування логістичної стратегії підприємств та визначає ефективність їх бізнеспроцесів. Саме тому важливим завданням є визначення основних складових, що впливають на стратегічне розміщення та рівень розвитку складської інфраструктури на макро-, мезо- і макрорівнях, оцінка основних механізмів впливу даних чинників та визначення основних інструментів стимулювання даного виду економічної діяльності.

Висновки. В сучасних умовах прискореного розвитку цифрових технологій на тлі глобальних викликів та суттєвих соціальних, економічних і геополітичних трансформацій забезпечення конкурентних переваг національних, регіональних економік та окремих бізнесів потребує нових адаптивних рішень, технологій та концепцій управління. Основним інструментом адаптації на сьогоднішній день виступають саме інновації, що базуються на новітніх досягненнях науки i техніки. Транспортно-логістичні системи виступають інтегруючою складовою економічних процесів, а від рівня їх організації та відповідності вимогам, що формуються в умовах сучасних перетворень залежить не тільки економічні результати систем всіх рівнів, а також національна безпека у всіх іiі проявах. Зважаючи на це, інноваційний розвиток транспортно-логістичних систем стає одним iз важливих стратегічних пріоритетів державного та регіонального менеджменту.

\section{Лimepamypa:}

1. Войт С.М., Завгородній К.В. Стратегічні орієнтири розвитку транспортно-логістичної інфраструктури України та її регіонів. Глобальні та національні проблеми економіки. 2015. Випуск 8. С. 730-732

2. Офіційний сайт Світового банку https://lpi.worldbank.org/international/scorecard/radar/ 254/C/UKR/2016/C/UKR/2014/C/UKR/2012/C/UKR/2010/C/UKR/2007?sort=asc\&order=Infrastruct ure\#datatable(дата звернення 18.05.2021 року)

3. Устенко М. А., Ивашкевич В.С. Перспективи розвитку транспортно-логістичних систем України. Вісник економіки транспорту і промисловості. 2017. № 59. С.84-90

4. Пархаєва Н. В., Колосова Б. В. Проблеми та перспективи розвитку логістичної інфраструктури в Україні. URL: http://eir.pstu.edu/bitstream/handle/123456789/5735/\%20.\% 20259.pdf?sequence $=1$ (дата звернення 19.05.2021 року)

5. Про схвалення Національної транспортної стратегії України на період до 2030 року. URL: https://zakon.rada.gov.ua/laws/show/430-2018-\%D1\%80\#Text(дата звернення 19.05.2021 року)

6. Стратегія сталої логістики та план дій уряд (проект до розгляду) URL: https://mtu.gov.ua/files/Logistics.pdf(дата звернення 19.05.2021 року)

7. Стратегія реформування управління життєвим циклом інфраструктурного проекту в Україні на 2020-2024 роки. URL: https://mtu.gov.ua/content/investoru.html(дата звернення 19.05.2021 року) 
8. Державна стратегія регіонального розвитку на 2020-2027 роки. URL: https://www.kmu.gov.ua/npas/pro-zatverdzhennya-derzhavnoyi-strategiyi-regionalnogo-rozvitku-na20212027-t50820(дата звернення 19.05.2021 року)

9. Іртищева І. О., Рогатіна Л. П., Крамаренко І.С., Андрющенко Є. Г., Білан В.В. Трансформація інвестиційної інфраструктури - запорука економічної безпеки: національний та регіональний аспекти. Агросвіт. 2020. № 12. С. 27-33.

10. Pavlova O., Pavlov K., Novosad O., Irtyshcheva I., Popadynets N., Hryhoruk I., Gelich N., Suriak A., Makara O., Zhuk O., Boiko Y., Kramarenko I. Strategic Priorities for Socio-economic Development of Ukraine in Comparison with the Republic of Poland. In: Karwowski W., Ahram T., Etinger D., Tanković N., Taiar R. (eds) Human Systems Engineering and Design III. IHSED 2020. Advances in Intelligent Systems and Computing, vol 1269. pp 308-314 https://doi.org/10.1007/978-3030-58282-1_49

11. Іртищева I. О., Тубальцева Н. П., Крамаренко І.С., Гришина Н. В., Сергійчук С.І. Економічний розвиток на засадах активізації малого підприємництва: історичні процеси та завдання управління. Економіка та держава. 2020. № 5. С. 75-80

\section{References:}

1. Voit, S.M., Zavgorodniy, K.V. (2015). Strategichni orijentyry rozvytku transportnologistychnoi' infrastruktury Ukrai'ny ta i'i' regioniv [Strategic guidelines for the development of transport and logistics infrastructure of Ukraine and its regions]. Global and national economic problems. 8. pp. 730-732 [in Ukrainian].

2. Oficijnyj sajt Svitovogo banku [Official website of the World Bank] Retrieved from https://lpi.worldbank.org/international/scorecard/radar/254/C/UKR/2016/C/UKR/2014/C/UKR/2012/ $\mathrm{C} / \mathrm{UKR} / 2010 / \mathrm{C} / \mathrm{UKR} / 2007$ ? Sort $=$ asc $\&$ order $=$ Infrastructure \# datatable (application date 18.05.2021) [in Ukrainian].

3. Ustenko M.A., Ivashkevich V.S. (2017). Perspektyvy rozvytku transportno-logistychnyh system Ukrai'ny [Prospects for the development of transport and logistics systems in Ukraine]. Bulletin of Transport Economics and Industry, 59, pp.84-90

4. Parkhaeva, N.V., Kolosova, B.V. (2021). Problemy ta perspektyvy rozvytku logistychnoi' infrastruktury v Ukrai'ni. [Problems and prospects for the development of logistics infrastructure in Ukraine]. Retrieved from http://eir.pstu.edu/bitstream/handle/123456789/5735/\%20.\%20259.pdf? sequence $=1$ (date date 19.05.2021) [in Ukrainian].

5. Pro shvalennja Nacional'noi' transportnoi' strategii' Ukrai'ny na period do 2030 roku [On approval of the National Transport Strategy of Ukraine for the period up to 2030]. Retrieved from https://zakon.rada.gov.ua/laws/show/430-2018-\%D1\%80\#Text(addition date 19.05.2021) [in Ukrainian].

6. Strategija staloi' logistyky ta plan dij urjad (proekt do rozgljadu) [Sustainable Logistics Strategy and Government Action Plan (draft for consideration)] Retrieved from https://mtu.gov.ua/files/Logistics.pdf (application date 19.05.2021) [in Ukrainian].

7. Strategija reformuvannja upravlinnja zhyttjevym cyklom infrastrukturnogo proektu $\mathrm{v}$ Ukrai'ni na 2020-2024 roky. [Strategy for reforming the life cycle management of the infrastructure project in Ukraine for 2020-2024.] Retrieved from https://mtu.gov.ua/content/investoru.html(date of application 19.05.2021) [in Ukrainian].

8. Derzhavna strategija regional'nogo rozvytku na 2020-2027 roky [State strategy of regional development for 2020-2027]. Retrieved from https://www.kmu.gov.ua/npas/pro-zatverdzhennyaderzhavnoyi-strategiyi-regionalnogo-rozvitku-na-20212027-t50820(date of appeal 19.05.2021) [in Ukrainian].

9. Irtyshcheva, I.O., Rogatina, L.P., Kramarenko, I.S. \& other. (2020). Transformacija investycijnoi' infrastruktury — zaporuka ekonomichnoi' bezpeky: nacional'nyj ta regional'nyj aspekty. [Transformation of investment infrastructure - the key to economic security: national and regional aspects]. Agrosvit. no. № 12, pp. 27-33. [in Ukrainian]. 
10. Pavlova, O., Pavlov, K., Novosad, O., Irtyshcheva, I. \& other. (2020). «Strategic Priorities for Socio-economic Development of Ukraine in Comparison with the Republic of Poland». Human Systems Engineering and Design III. IHSED 2020. Advances in Intelligent Systems and Computing. vol. 1269, pp 308-314 [in English].

11. Irtyshcheva, I.O., Tubaltseva, N.P., Kramarenko, I.S., Grishina, N.V. and Sergiychuk, S.I. (2020). Ekonomichnyj rozvytok na zasadah aktyvizacii' malogo pidpryjemnyctva: istorychni procesy ta zavdannja upravlinnja. [Economic development on the basis of activation of small business: historical processes and management tasks]. Ekonomika ta derzhava. [Economy and state]. no. 5, pp. 75-80 [in Ukrainian]. 